\title{
sciendo
}

\section{Strategic management in Japanese tourism industry during the COVID-19 pandemic}

\author{
Alexandra-Gabriela BARANYI \\ Bucharest University of Economic Studies, Bucharest, Romania \\ baranyi.alexandra@yahoo.ro
}

\begin{abstract}
In recent years, Japan proved to be one of the world's leading countries in the travel industry by international tourist arrivals, with many other businesses relying on foreign travelers' consumption within the country. The current Covid-19 pandemic crisis is a challenge for the tourism industry all around the world, as well as for Japan, where the entry restrictions have been strict since the start of the pandemic, foreigners not being allowed to enter the country for leisure purposes. However, even though the national income in this economic area decreased, it is still very high compared with other countries, and many businesses managed at least to maintain their activity on the market. In this paper, I will first analyze what were the strategic measures the Japanese government had taken regarding the national tourism industry during the SARS epidemic at the beginning of the 21st Century. Further, I will compare those measures with the government's attitude over Japan's travel industry in the first year of the current pandemic. Furthermore, I will make a comparison of the national income in the travel industry and the number of tourists by major areas in 2020 and the previous year, in order to introduce some strategic measures that could improve Japanese tourism for the next period, considering that the Tokyo 2021 Olympic Games will be held this summer.
\end{abstract}

Keywords: Japan, Travel Industry, Strategic Measures, Health Crisis, Olympic Games.

\section{Introduction}

The travel industry in the current era is crucial for many countries' economies worldwide, and the pandemic has caused lots of disturbances for this market. The GDP rate or the unemployment rate, especially for those who were previously working in hotels, restaurants, and other businesses related to tourism, are just some of the indicators that show a decreasing tendency.

In Japan's case, tourism was not the main income source for the nation's economy, as it maintained a constant contribution of $7 \%$ in GDP values (OECD, 2018), but still, Japan is the $11^{\text {th }}$ country worldwide by international tourist arrivals. The fact that the Japanese economy is mainly based on production and soft industry, helped them survive the present health crisis.

Since the beginning of the year 2020, Japan closed its border for foreign residents coming for leisure purposes and increased the restrictions regarding abroad departures for national residents. Although at a first glance this might seem to be a hurdle for the travel industry, Japan managed to introduce lots of programs to sustain the tourism businesses by facilitating travel procedures and encouraging residents to go on trips inside Japan.

Also, as the current Covid-19 pandemic is not the first health crisis Japan had withstood, it is necessary to analyze what were the strategic measures the state had adopted during the SARS epidemic (2002-2003) and how was the travel industry affected back then. Furthermore, this comparison will highlight how crisis management strategies have improved in the course of almost two decades.

The purpose of the following research is to analyze the effects of the current pandemic situation on the Japanese travel industry, considering all the programs that the government had to introduce to sustain those businesses dependent on tourism activity. By evaluating the main 
indicators of the travel industry - such as the national income from tourism activity, the number of national and foreign resident tourists in Japan, and their expense tendency - I will also describe some scenarios for the Tokyo 2021 Olympic Games. Besides this, my contribution to this research will consist of proposing some strategic measures that could enhance the activity in the Japanese travel market, as well as facilitate the condition for the Olympic Games.

\section{Literature review}

\section{Main Aspects of Japanese Travel Industry}

The Japanese tourism industry started to develop a lot since the end of the '90s, with 4.5 million foreign visitors per year and kept a growing tendency until 2019, when more than 30 million foreigners were registered.

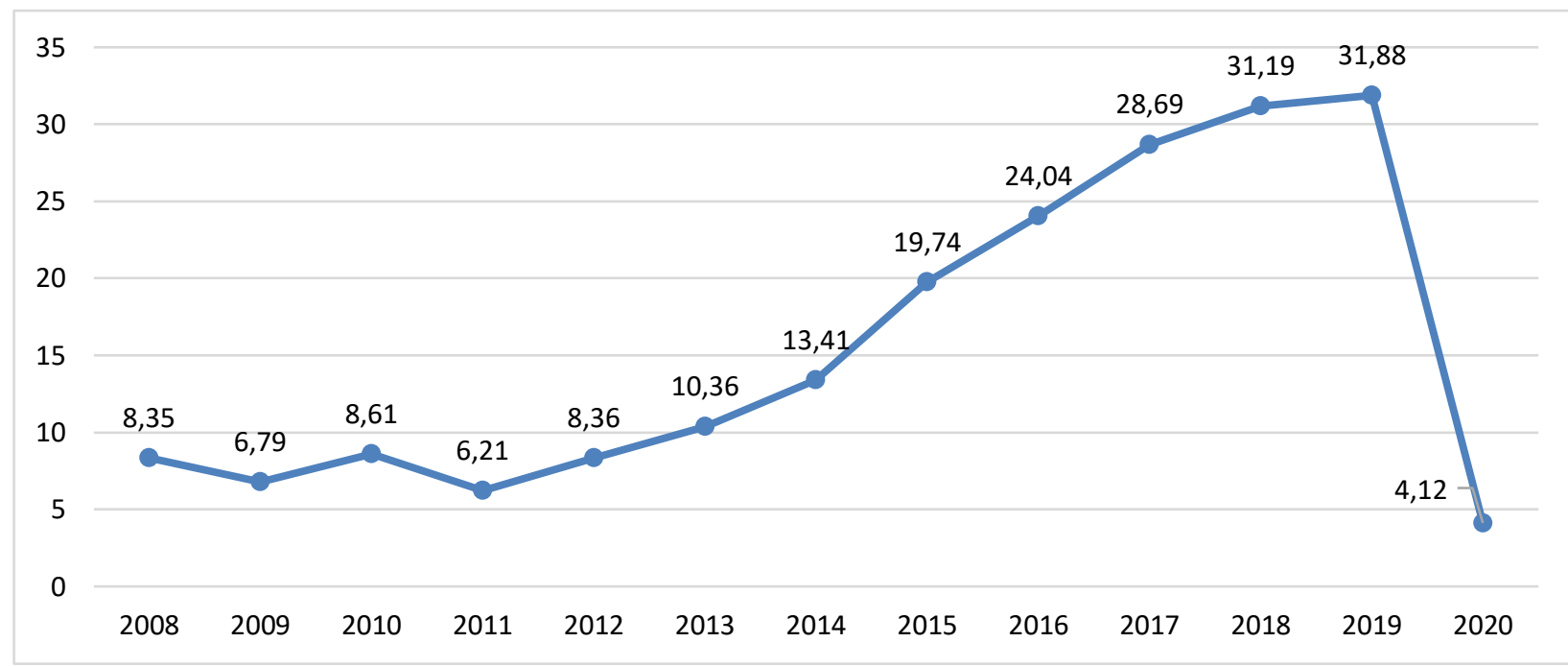

Figure 1. Overseas Residents Visits (in millions)

Source: www.tourism.jp/en/tourism-database/stats/inbound/.

After 2010 - excluding 2011, the year of the Fukushima nuclear disaster - Japan has experienced a consistent increase of overseas travelers every year, and some notable economic and cultural reasons need to be mentioned. Being an island, the main access means is by air and the fact that many airlines have dropped the prices in the last decade had a great contribution to the increasing number of travelers here. Besides, the boost in interest for Japan as a destination is very much related to the appetite for Japanese pop culture, as in anime, manga, music, and video games culture, which had a big hit since the end of the $20^{\text {th }}$ Century. Some of those are already in their 20 's and they have the necessary resources for travel, but we must not bypass the older generations, for which the Japanese culture - with its traditional values and concepts here - was again a point of interest worldwide. Another reason that boosted the tourism in Japan was the fact that they tried to approach an English-friendly position for all the main tourist attractions, as language was the main barrier back at the end of the '90s. In addition, as the Japanese pop culture was already conquering the Internet in the last year, Japan benefited from online promotion, such as bloggers and vloggers content, cultural centers, travel agencies, and so on, who were using social media to induce people the need for a trip here. 
It is also important to see what the proportion of those overseas visitors from the total number of tourists in Japan really is.

Table 1. Total number of tourists with at least one stay (in millions)

\begin{tabular}{|c|c|c|c|c|c|c|c|c|c|c|}
\hline & $\mathbf{2 0 1 1}$ & $\mathbf{2 0 1 2}$ & $\mathbf{2 0 1 3}$ & $\mathbf{2 0 1 4}$ & $\mathbf{2 0 1 5}$ & $\mathbf{2 0 1 6}$ & $\mathbf{2 0 1 7}$ & $\mathbf{2 0 1 8}$ & $\mathbf{2 0 1 9}$ & $\mathbf{2 0 2 0}$ \\
\hline $\begin{array}{c}\text { National } \\
\text { Resident } \\
\text { Tourists }\end{array}$ & 313.56 & 315.55 & 320.42 & 297.34 & 312.99 & 325.66 & 323.33 & 291.05 & 311.62 & 198.02 \\
\hline $\begin{array}{c}\text { Overseas } \\
\text { Resident } \\
\text { Tourists }\end{array}$ & 6.21 & 8.36 & 10.36 & 13.41 & 19.74 & 24.04 & 28.69 & 31.19 & 31.88 & 4.12 \\
\hline
\end{tabular}

Source: https://www.mlit.go.jp/common/001344254.pdf.

The number of national residents' visits inside the country is a lot higher than the overseas tourists' one, even though the last one is still very high in comparison with other countries. Some main aspects have to be taken into account: the working system in Japan does not facilitate long-period trips for the Japanese residents, in addition to the fact that being an island country, most of the outbound destinations are accessible only by airplane. And so, many residents prefer choosing an inbound destination for travel.

Also, for both cases, the national residents and the foreign residents, leisure and business are the main travel purposes of Japan's major cities (Tokyo, Kyoto, and Osaka) being the most visited destinations (JNTO, 2021).

Before the Covid-19 Pandemic, the Japanese government together with the national travelrelated businesses introduced many facilities that simplified the inbound tourism for overseas residents. From the beginning of the $21^{\text {st }}$ Century, as Japan Travel Bureau started to invest a lot in promoting Japan as a complete destination for all types of leisure tourism, hotels, transportation facilities, museums, and shops introduced English translations, in order to become a foreignfriendly destination. In 2019 the place of origin for most overseas tourists are the Asian countries: $30.1 \%$ China, $17.5 \%$ South Korea, $15.3 \%$ Taiwan, but only $6.2 \%$ for Europe and $6.9 \%$ for North America (JTB, 2021). Despite that proportion for non-Asian countries seems very small, there is a growing tendency, compared with the previous year. In addition to this, the period of stay in Japan for tourists coming especially from European countries is much longer compared with Asians, as the transportation time exceeds 12 hours. When traveling for leisure purposes, the average period of stay is from 7 to 14 days, so the expenses might be higher for those than for the tourists coming from China, South Korea, or Taiwan.

\section{Japanese Tourism Management during SARS epidemic}

The SARS Epidemic started in 2002 and in the course of one year, it infected 8096, with a death rate of 9.6\% (World Health Organisation, 2004). The Asian countries were the most affected by this, starting with China, the place where the epidemic outraged, continuing with Taiwan and South Korea, not only regarding the number of cases but in terms of the national economy as well. The symptoms being very severe, with a mortality rate of almost $10 \%$, the state of emergency was necessary for some Asia Pacific countries including the above-mentioned three. However, the Japanese did not report any cases of SARS, being very cautious regarding travel activity to other Asian countries (Mao et al., 2010).

The restrictive measures here included quarantine of suspects, medical checks for all arriving passengers who were declared as suspects after thermal imaging. Still, besides the travel 
restriction that had the objective of reducing the risk of spreading between countries, there were no other legal restrictions implemented.

Still, in a context where more than $50 \%$ of the overseas visitors are originating from Asian countries, notably China, South Korea, and Taiwan, the incoming rate in Japan decreased to 24.3\% in 2003 (Malcolm, 2006). The overseas departures in Japan also decreased by more than 55\%. All the countries that presented SARS cases had to introduce many restrictions for outbound tourism, especially in the second year after the outrage, all the trips, no matter if with leisure or business purposes, had to be canceled between April and June 2003. Even besides the months of restrictions, national residents of Asia Pacific countries were advised to avoid outbound travel. The media and press had a great influence here as they insisted a lot, in some cases even exaggerating, on the risk of spreading the virus, which eventually caused people to be very precocious about traveling outside.

Japan suffered a loss in tourism income, but at the same time, the government approached a strategic measure promoting inbound tourism for its nationals. For the Japanese as well, those neighboring countries were the most frequented destinations, so the entry restrictions were at the same time an opportunity for an inbound travel boom.

\section{The Impact of Covid-19 in Japan - Consequences for the Japanese Travel Industry}

The first case of Covid-19 here was reported on January $16^{\text {th }}$ in Kanagawa prefecture and started to rapidly spread since the beginning of March 2020. As Japan had been through a similar context in 2003, during SARS Epidemic, in order to slow down the growing tendency of new coronavirus cases, the first measure that they took was to first close its border for foreign residents' arrival, and national departures, except the trips that are really necessary. In those cases, they imposed a negative test before departure and 14 days quarantine after arriving in Japan (Content, 2020). In comparison with the previous epidemic when the entry restriction only lasted for three months, in the current pandemic the restriction has not been lifted since March 2020.

A second main measure was to encourage businesses to implement telework systems. As other industries could continue their activity online, and somehow sustain their position in the market, travel-related businesses were the most affected ones during this period. As seen in Figure 1 , the overseas tourists' arrivals reported a $-97.7 \%$ decreasing tendency for 2020. Many hotels, restaurants, and travel agencies were dependent on foreign travelers' expenditure, so they had to adapt and find other alternatives to survive. Japan has also introduced a national lockdown during the first months of the pandemic, during which restaurants and bars were forced to pause their activity. The measure only lasted two months as a national restriction and it was maintained afterward only for the prefectures with a high rate of infection.

Asia Pacific overall Travel and Tourism GDP loss in 2020 was reported at 1.475 billion dollars (Lin, 2020). Japan suffered lots of losses, as in March 2020 they already had scored -3 billion dollars revenue from the travel industry. From the moment when the restrictions were introduced the bus industry dropped $79 \%$ of revenue by the end of the year, Shinkansen trains worked with only half of the usual customer numbers. During lockdown (March-May) dropped 90\% in booking and national airlines scored a 4 billion dollars loss (Kayama, 2020).

Regardless of the government's supportive measures, the unemployment rate increased (Japan Macro Advisors, 2021), and 2800 out of 9 million people working in the travel industry have lost their job by August 2020, most of them being women (Lin, 2020). In the aftermath, Japan registered a rising suicide rate, mostly among women. In October 2020 it the suicide rate among women was $83 \%$ higher than the same month in the previous year (Wang et al., 2020). As the 
overall unemployment rate increased lately, scoring its peak in October 2020, of $2.14 \%$, this proved to be one of the main drivers that were driving female nationals to take their lives. Most of those were at the same time single-mothers, an issue that added pressure to the unemployment condition.

\section{Strategic Measures Taken by the Japanese Government to Sustain the Travel Industry}

After introducing all the travel restrictions, Japan needed to make a decision about the Tokyo 2020 encouraging, they had to postpone it for 2021.

The first decisions made were to fuel the national economy by offering financial support for its nationals. After offering special loans for its nationals to return from other countries, they invested in the medical industry, helping hospitals to increase their capacity, as well as providing all the needed materials to face the health crisis. The third financial support package, in March 2020, valued at 1.1 trillion USD (KPMG, 2020), was redirected to all private entities to support their losses during the next period, 15 billion USD of those especially for the travel industry (Travel Voice, 2020). Being in a situation where the national travel and tourism industry was still sinking, despite the government's financial help, they came up with another strategy, that of supporting domestic tourism activity. There is a tendency that was specific even during the SARS epidemic, and other crises where Japan is assisting the national economic activity with countries own resources - a position approached by Japanese in other socio-political and economic contexts as well (Proganó, 2020).

A strategic measure Japan has adopted is the Go to Travel campaign, launched in July 2020. It was very much promoted months before it was initiated via the internet, especially social media, in order to get exposure. The campaign was offering a 50\% discount for the inbound travels for the national residents from the government. It was introduced as a cash-back system, where tourists were receiving coupons to use at the destination in order to receive the discounts (Ministry of Land, Infrastructure, Transport and Tourism, 2020). As at the same time this implied a higher risk for the virus to spread all over Japan, there were some specific restrictions. Tokyo was excluded from the program because of the increasing number of cases, as well as Okinawa, during the August period and all the trips there were suggested to be replanned.

Still, this campaign helped lots of tourism-related businesses to maintain their activity and at the same time, it offered residents the occasion to travel, despite the restrictions regarding international departures.

\section{Methodology}

The purpose of this research is to analyze the impact of COVID-19 on the travel industry in Japan and what were the strategic measures approached by the Japanese government to sustain the tourism-related businesses. As the Tokyo 2020 Olympic Games were postponed to 2021, this research aims to describe in previous analysis the scenario for the Tokyo 2021 Olympic Games.

The aim of this paper being related to a current context, previous research papers that approached the same direction are still not available. Still, in order to have a comparison with a similar situation, I will refer to a few research papers about the impact of the SARS epidemic on the tourism industry in Japan. Also, this will lead to more consistent results, creating the opportunity to see if the government's strategic measures present a similar tendency in both cases.

The fact that they fueled the national economy by giving financial aid from their own resources to private industries in both cases proves that Japan is very much oriented to internal support, independent from other outside sources. Of course, during the SARS epidemic, the losses 
did not feel so much in other industries besides travel and tourism as the crisis level was lower than the current pandemic. And so, the government tried to increase tourism activity by promoting inbound travel to its nationals, rather than increase the financial support measures. In the Covid-19 case, the rising rate of infection made it hard for the Japanese to travel inside the country as well, so the Go to Travel campaign was a lifesaver for tourism-related businesses.

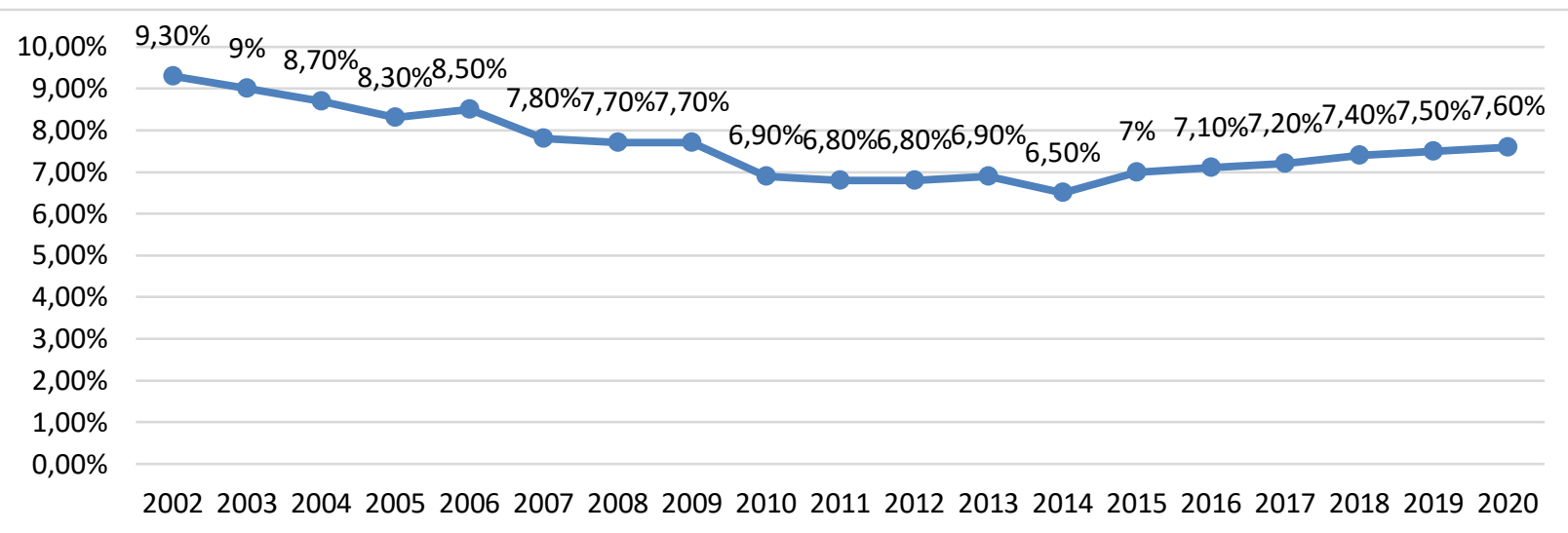

PICBE |

Figure 2. Travel and Tourism Contribution to GDP in Japan

Source: https://knoema.com/atlas/Japan/topics/Tourism/Travel-and-Tourism-Total-Contribution-toGDP/Contribution-of-travel-and-tourism-to-GDP-percent-of-GDP.

As seen in Figure 2, the overall travel and tourism contribution to Japan's GDP did not suffer substantial changes, neither during the SARS epidemic nor the Covid 19 pandemic. Eventually, there were some decreasing cases reported in some specific months, at the beginning of both crises, but as the government started to apply all the financial and legal supportive measures, the situation came back to its track.

\section{Results and discussions}

After analyzing Japan's position for reviving the travel industry during the SARS epidemic at the beginning of the $21^{\text {st }}$ century and at the time of the Covid-19 pandemic, we can define a similar direction for the strategic measures that were taken.

In both cases, Japan adopted an approach through which it could actually enhance the tourism activity within the country, by still keeping its border closed for overseas visitors. Therefore, they encouraged national residents to travel within the country, at the same time supporting the tourism-related businesses with programs and campaigns that could cover a part of the costs.

Still, the Covid-19 had a great impact on the travel market, which suffered big losses that could not be covered by any measure, at the time of health crises. The problem left to be analyzed is what are the possible future losses, as the current pandemic is far from an ending point at an international level so the entry restrictions cannot be lifted.

Besides the overall national losses, the postponement of the Tokyo 2020 Olympic Games involved big costs for all the organizing entities: for the Tokyo Metropolitan Government 1.1 billion dollars, the organizing committee 968 million dollars, and 667 million dollars for Japan's government (Tarrant, 2020). The International Olympic Committee will help Japan cover some of the above-mentioned costs, but it is still a big strike for all the organizers. 
Regarding the Tokyo 2021 Olympic Games which is expected to be held from 23 July to 8 August 2021, followed by the Paralympic Games from August $24^{\text {th }}$ to September $5^{\text {th }}$, there are a few steps that could help Japan prepare a secure environment in order to have the event taking place this year. A collaboration between private and public companies could help them prepare a special infrastructure to sustain a big number of foreigners at the same place at the same time, but of course, that also includes well-implemented strategic management so that those overseas arrivals would not interfere with nationals' activity that could increase the risk of spreading the virus (Japan Travel Trade News, 2020).

The organizers' voices are divided, some stating that there is no chance for the great event to take place this year as Japan's rising rate of infections and the tourist entry restrictions are planned to last until May 8 (Roan, 2021). Japan's officials are, on the contrary, optimistic regarding the current situation and say that the Olympic Games will take place amid rising infections. As a future scenario is almost impossible to be provided, the decision towards another postponement initiative should be taken as soon as possible, avoiding the costs' rising.

\section{Conclusion}

The travel industry in Japan before the pandemic was very prosperous with a record of foreign residents' arrivals in 2019, and the current situation provoked many losses for Japan's economy, especially in the travel industry, with the Tokyo 2020 Olympic Games being postponed for 2021. Still, the fact that Japan encountered a similar context during the SARS epidemic, helped the government approach a revival strategy that at the same time did not interfere with the health crisis measures.

The current research encounter limitations concerning the lack of previous studies on the same area as the stated issues are still ongoing. Furthermore, the data was also not enough to come up with consistent quantitative research, also taking into account that the aim was to describe the context for the Tokyo 2021 Olympic Games. After more data and other research papers will be available, the analysis can be developed.

\section{References}

Content., S. (2020). Bcc Japan. Resilience and Adaptation for Japan's Travel and Tourism Industry, Retrieved from https://bccjapan.com/news/travel-and-tourism-think-tank-iitravel-and-resilience/.

Japan Macro Advisors (January 2021). Unemployment in Japan remained unchanged at $2.9 \%$ in December 2020, Japanese Macroeconomic Data, Retrieved from https://www.japanma croadvisors.com/page/category/economic-indicators/labor-markets/unemployment-rate/.

Japan Travel Trade News (2020). What is happening in the travel industry of Japan? What should be done next with COVID-19?, Retrieved from https://www.travelvoice.jp/english/what-ishappening-in-the-travel-industry-of-japan-what-should-be-done-next-with-covid-19-trave 1-voice-live-report.

JNTO (2021). 日本の観光統計データ (Japan Tourism Statistics), Retrieved from https:// statistics.jnto.go.jp/en/graph/\#graph--average--length--of—-stay.

JTB Tourism Research and Consulting Co (2021). Japan-bound Statistics. Overseas Residents' Visits to Japan, Retrieved from www.tourism.jp/en/tourism-database/stats/inbound/. 
Kayama, T. (2020). Lynk News \& Insights. How is COVID-19 Impacting Japan's Tourism Industry?, Retrieved from https://www.blog.lynk.global/2020/04/07/opinion-how-iscovid-19-impacting-japans-tourism-industry/.

KPMG (2 December 2020). Japan Government and institution measures in response to COVID19, Retrieved from https://home.kpmg/xx/en/home/insights/2020/04/japan-governmentand-institution-measures-in-response-to-covid.html.

Lin, A. (2020). The Impact of COVID-19 on Japan's Tourism Industry, Retrieved from https://storymaps.arcgis.com/stories/6702b45af4e74607b951c0279c54ab53.

Malcolm, C. (2006). Japanese Tourism and the SARS Epidemic of 2003, Journal of Travel \& Tourism Marketing, 19:2-3, 117-131, DOI: 10.1300/J073v19n0210.

Mao, C. K., Ding, C. G., \& Lee, H. Y. (2010). Post-SARS tourist arrival recovery patterns: An analysis based on a catastrophe theory, Tourism Management, 31(6), 855-861, https://doi.org/10.1016/j.tourman.2009.09.003.

Ministry of Land, Infrastructure, Transport and Tourism (2020) 旅行 - 観光消費動向調査 (Survey over Travel and Tourism Consumption Tendency), Retrieved from https://www .mlit.go.jp/common/001344254.pdf.

OECD (2018). Tourism GDP. Retrieved from https://data.oecd.org/industry/tourism-gdp.htm

Proganó, R. N. (2020). Wakayama University. [研究コラム] (Vol. 2) The COVID-19 pandemic impact on Japanese inbound tourism, Retrieved from https://www.wakayamau.ac.jp/ctr/news/2020101400019/.

Roan, D. (19 January 2021). Tokyo Olympics 'unlikely to go ahead in 2021'. BBC News, Retrieved from https://www.bbc.com/news/business-55722542.

Tarrant, J. (4 December 2020). Japanese organisers say 2020 Games delay to cost them $\$ 2.8$ billion. Reuters, Retrieved from https://www.reuters.com/article/us-olympics-2020-costsidUSKBN28E0WM.

Travel Voice (11 March 2020). 政府、新型コロナ緊急策第2弾で「観光業を強力に下支え」

、雇用・資金繰り対策や受入整備事業などで (The Japanese government supports the tourism industry under the second emergency package against the novel coronavirus), Retrieved from https://www.travelvoice.jp/20200311-145655.

Wang, S., Wright, R. \& Wakatsuki, Y. (30 November 2020). In Japan, more people died from suicide last month than from Covid in all of 2020. And women have been impacted most. CNN News, Retrieved from https://edition.cnn.com/2020/11/28/asia/japan-suicidewomen-covid-dst-intl-hnk/index.html.

World Health Organization (2004). Epidemic Alert and Response. WHO guidelines for the global surveillance of severe acute respiratory syndrome (SARS), Retrieved from https://www. who.int/csr/resources/publications/WHO_CDS_CSR_ARO_2004_1.pdf. 